\title{
PENGEMBANGAN BAHAN AJAR PADA MATA PELAJARAN PPKN
}

\author{
Muhammad Ridwan ${ }^{1}$, Sahat Siagian ${ }^{2}$ \\ Teknologi Pendidikan Program Pascasarjana Universitas Negeri Medan \\ muhammad_ridwan@yahoo.com ${ }^{1}$
}

\begin{abstract}
Abstrak: Penelitian dan pengembagan ini bertujuan: (1) mengambangkan bahan ajar mata pelajaran PPKn; (2) mengetahui efektifitas produk bahan ajar pada mata pelajaran PPKn yang dikembangkan. Metode penelitian adalah penelitian dan pengembangan dengan menggunakan model Borg and Gall. Hasil penelitian menunjukkan; (1) validasi untuk kelayakan isi bahan ajar PPKn adalah baik, (2) validasi untuk kelayakan penyajian bahan ajar PPKn adalah baik, (3) validasi untuk kelayakan isi bahan ajar adalah baik, (4) validasi untuk kelayakan penyajian bahan ajar adalah baik, (5) validasi untuk kelayakan bahasa bahan ajar adalah baik, rentang validasi akhir dari bahan ajar PPKn hasil pengembangan adalah baik, yang artinya bahan ajar PPKn hasil pengembangan dinyatakan valid. Hasil pengujian hipotesis membuktikan bahwa terdapat perbedaan yang signifikan antara hasil belajar siswa yang dibelajarkan dengan menggunakan bahan ajar PPKn hasil pengembangan dengan hasil belajar siswa yang dibelajarkan dengan menggunakan buku teks. Hal ini ditunjukkan dengan hasil pengolahan data dimana diperoleh $t_{\text {hitung }}$ sebesar 8,666 sedangkan $t_{\text {tabel }}=2,042$, pada $\alpha=0,05$ dengan dk 98 . Hasil perhitungan dimana $t_{\text {hitung }}>t_{\text {tabel, }} t_{\text {hitung }}$ yaitu 8,666 $>2,042$. Disimpulkan bahwa jumlah rata-rata nilai postes hasil belajar kelompok siswa yang dibelajarkan dengan menggunakan bahan ajar PPKn hasil pengembangan adalah sebesar 80,667 dan lebih tinggi dari kelompok siswa yang dibelajarkan dengan menggunakan buku teks, yaitu sebesar 55,333.
\end{abstract}

\section{Kata Kunci: bahan ajar pada mata pelajaran PPKn}

Abstract: Research and pengembagan aims: (1) floating the subjects PPKn instructional materials; (2) determine the effectiveness of the product instructional materials on subjects PPKn developed. The research method is a research and development using the Borg and Gall models. The results showed; (1) validation of the feasibility of the contents of teaching materials PPKn is good, (2) validation of the feasibility of presenting instructional materials PPKn is good, (3) validation of the feasibility of the contents of teaching materials is good, (4) validation of the feasibility of the presentation of teaching materials is good, (5) validation of the feasibility of language teaching materials is good, the ultimate validation range of teaching materials PPKn result of the development is good, which means the development of teaching materials PPKn result declared invalid. Hypothesis testing results prove that there is a significant difference between the learning outcomes of students that learned to use teaching materials PPKn results with the development of student learning outcomes that learned to use textbooks. This is indicated by the data processing which gained tcount of 8.666 while the table $=2.042$, at $\alpha=0.05$ with $98 \mathrm{hp}$. The results of calculations where thitung > ttable, thitung namely 8.666>2.042. It was concluded that the amount of the average value group posttest learning outcomes of students that learned to use teaching materials PPKn development results amounted to 80.667 and was higher than the group of students that learned to use textbooks, which amounted to 55,333.

Keywords: teaching materials on subjects PPKn

\section{PENDAHULUAN}

Pengembangan bahan ajar salah satu upaya untuk mengatasi kesenjangan antara kondisi ideal dengan kondisi riil yang ada di lapangan. Kondisi ideal yang dimaksud adalah seperti: ketersediaan model bahan ajar harus sesuai dengan karakteristik konsep bidang mata pelajarannya untuk meningkatkan hasil pendidikan yang terpadu tidak hanya dari segi kognitif (pengetahuan), akan tetapi dilengkapi dengan pendidikan karakter sesuai tuntutan kurikulum yang berlaku

Menurut Holliday (2002), ada lima hal yang harus dipertimbangkan dalam buku pelajaran siswa menengah yaitu : isi dari buku dan informasi terkait, penjelasan buku pelajaran 
yang baik dan masuk akal, menarik dan memotivasi siswa untuk belajar, pertimbangan dihubungkan dengan siswa yang unik, sekolah, komunitas dan materi pendukung yang dirancang untuk siswa dan buku yang dihasilkan guru dibiayai oleh penerbit yang bereputasi. Agar buku mempunyai asas manfaat yang tinggi, pengarang juga menyajikan ketajaman dan jangkauan informasi yang dapat dipelajari melalui bukunya. Buku yang baik memuat visi (arah), misi (pesan), konteks (kaitan), konten (isi) dan proses dari suatu informasi (Martono, 2005). Buku pelajaran dapat juga menjadi media pembelajaran yang sangat berarti apabila buku pelajaran tersebut digunakan sebagai alat komunikasi untuk membawa informasi akurat dari sumber belajar kepada pembelajar. (Silitonga dan Situmorang, 2009).

Yamin (2009), Buku pelajaran sangat efektif sebagai media pembelajaran karena (1) Penyampaian materi pelajaran dapat diseragamkan, (2) Proses pembelajaran menjadi lebih menarik dan interaktif, (3) Jumlah waktu belajar-mengajar dapat dikurangi, (4) Kualitas belajar siswa dapat ditingkatkan, (5) Proses belajar dapat dilakukan dimana dan kapan saja, (6) Sikap positif siswa terhadap bahan pelajaran maupun terhadap proses belajar dapat ditingkatkan, (7) Peran guru dapat berubah kearah yang lebih positif dan produktif.

Melalui buku teks pelajaran peserta didik diharapkan dapat memperoleh informasi yang lebih terjamin keakuratannya karena informasi tersebut diperoleh dari sumber lain selain dari guru. Sejalan dengan paradigma pendidikan bergeser dari guru sebagai pusat pem-belajaran (teacher centered) kepada peserta didik sebagai pusat pembelajaran (student centered), peserta didik perlu didorong dan diberi peluang untuk mencari informasi dari berbagai macam sumber, seperti buku teks pelajaran, secara mandiri. Oleh karena itu, buku teks pelajaran sebagai sumber informasi seyogjanya memiliki kualitas yang baik, yang memenuhi kriteria standar tertentu.

Hamalik (2008) menyatakan tiga faktor yang memengaruhi keberhasilan suatu implementasi kurikulum, yakni dukungan kepala sekolah, dukungan rekan sejawat guru, dan dukungn internal dalam kelas. Dari faktor-faktor tersebut guru merupakan faktor penentu utama dalam keberhasilan implementasi kurikulum, karena guru lah yang berperan sebagai implementator utama dalam pembelajaran, yakni sebagai manajer pembelajaran dalam kelas.. Guru sebagai manajer pembelajaran yang baik dalam proses pembelajaran tentu harus memiliki kreatifitas yang tinggi dalam mengelola kelasnya, salah satunya adalah dalam hal pemilihan dan penggunaan media dan sumber belajar untuk kepentingan proses pembelajaran. Implementasi kurikulum 2013 direncanakan dilengkapi dengan buku siswa dan pedoman guru yang disediakan oleh Pemerintah. Strategi ini memberikan jaminan terhadap kualitas isi/bahan ajar dan penyajian buku serta bahan bagi pelatihan guru dalam keterampilan melakukan pembelajaran dan penilaian pada proses serta hasil belajar peserta didik. Pada bulan Juli 2013 yaitu pada awal implementasi Kurikulum 2013 buku seharusnya sudah dimiliki oleh setiap peserta didik dan guru. Namun kenyataannya dilapangan pengembangan kurikulum tidak sejalan dengan pengembangan terhadap sarana prasarana yang dibutuhkan tersebut. Pemerintah sudah melunjurkan kurikulum 2013 tersebut tetapi buku pedoman guru dan pegangan siswa belum mampu terpenuhi.

Buku sebagai salah satu sumber harus dapat mendukung proses dan pencapaian tujuan belajar, dapat membangkitkan motivasi dan minat belajar siswa. Selain buku teks yang kurang sesuai standar kompetensi dan kompetensi dasar, kurangnya kemampuan guru untuk menyediakan bahan ajar sebagai salah satu media dan sumber belajar, kemampuan menggunakan strategi pembelajaran yang sesuai dengan karakteristik mata pelajaran terkesan monoton dan tidak diperkaya dengan hal-hal baru yang melibatkan siswa dalam kegiatan pembelajaran,sehingga siswa cenderung hanya menerima dan menghapal konsep yang diberikan tanpa mengetahui hubungan antara pengetahuan yang diperoleh dengan penerapannya dalam kehidupan sehari-hari terutama dalam bertindak, berperilaku dan memecahkan masalah yang ada disekitarnya (Angelina, 2010). Melihat

besarnya peranan PPKn dalam kehidupan berbangsa dan berNegara, tuntutan yang muncul untuk guru PPKn adalah bagaimana guru dapat membelajarkan siswa sehingga pembelajaran PPKn menjadi bermakna dengan didasarkan pada pilar-pilar belajar (learning to know, learning to do, learning to be, and learning to live together) dan pembelajaran yang sesuai konteksnya dengan kehidupan alam, realistik 
serta menerapkan penilaian (assesmen) berbasis kompetensi.

Hal penting dalam merancang bahan ajar adalah bahwa organisasi isi bahan ajar harus berpijak pada karakteristik struktur isi mata pelajaran yang sesuai dengan apa yang diamanat dalam kurikulum yang berlaku, sehingga dapat meningkatkan perolehan belajar dan retensi daripada sekedar mengikuti urutan isi buku teks. Reigeluth (1992) juga menyarankan sebaiknya rancangan bahan ajar memodifikasi salah satu model baku (standard blue print) yang paling sesuai dengan kebutuhan khusus pembelajaran. Peserta didik yang berhubungan dengan sumber belajar mempelajari pesan akan melakukan internalisasi dan diduga meningkatkan ranah kognitif, afektif, maupun psikomotoriknya.

Bahan ajar merupakan komponen isi pesan dalam kurikulum yang harus disampaikan kepada siswa. Komponen ini memiliki bentuk pesan yang beragam, ada yang berbentuk fakta, konsep, prinsip/kaidah, prosedur. Dalam Yaumi, M (2013) Pengertian bahan pembelajaran adalah seperangkat bentuk yang disusun untuk kebutuhan belajar. Bahan pembelajaran juga disebut learning materials (bahan Ajar) yang mencakup alat bantu visual seperti handout, slides/overheads, yang terdiri atas teks, diagram, gambar dan foto, serta media lain seperti audio, video, dan animasi.

$$
\text { Menurut Dick dan Carey (1996) }
$$

pengembangan bahan ajar meliputi: (1) mengidentifikasi kebutuhan untuk menetapkan tujuan, (2) melakukan analisis pembelajaran, (3) mengidentifikasi karakteristik siswa, (4) merumuskan tujuan performansi, (5) mengembangkan acuan patokan, (6) mengembangkan startegi pembelajaran, (7) mengembangkan dan memilih materi pembelajaran, (8) merencanakan dan melakukan evaluasi sumatif.

Dalam Yaumi, M (2013) Bahan ajar dapat dibagi tiga jenis, yaitu: Bahan cetak, bahan bukan cetak, dan kombinasi cetak-bukan cetak. Bahan pembelajaran merupakan wujud pelayanan satuan pendidikan terhadap peserta didik. Pelayanan individu peserta didik dapat tercipta dengan baik melalui bahan ajar yang dikembangkan secara khusus yang berpedoman terhadap kurikulum yang sedang berlaku saat itu. Terdapat enam langkah pengembangan bahan ajar, yaitu: Mempersiapkan garis-garis besar bahan pembelajaran, Melakukan penelitian, Menguji bahan pembelajaran yang tersedia, .
Menyediakan dan memuat bahan pembelajaran, serta Menyeleksi atau menyediakan aktivitas pembelajaran. pembelajaran, maka setiap bahan ajar harus memenuhi komponen-komponen yang relevan dengan kebutuhan pebelajar. Komponen-komponen tersebut juga harus dapat memberikan motivasi, mudah dipelajari dan dipahami pebelajar. Lebih penting lagi adalah relevan dengan sifat mata kuliah yang disajikan. Selain itu, bahan ajar juga harus memiliki karakteristik tertentu yang membedakannya dengan buku-buku yang lainnya (Degeng, 1989).Bahan ajar yang dapat memudahkan belajar adalah bahan ajar yang memiliki komponen-komponen yang jelas berupa: (1) tujuan umum pembelajaran, (2) tujuan khusus pembelajaran, (3) petunjuk khusus pemakai buku ajar, (4) uraian isi pelajaran yang disusun secara sistematis, (5) gambar/ illustrasi untuk memperjelas isi pelajaran, (6) rangkuman, (7) evaluasi formatif, dan tindak lanjut untuk kegiatan belajar berikutnya, (8) daftar bacaan, dan (9) kunci jawaban.

Dalam Mulyasa (2013) Kurikulum 2013 dirancang dengan karakteristik sebagai berikut: (1) mengembangkan keseimbangan antara pengembangan sikap spiritual dan sosial, rasa ingin tahu, kreativitas, kerja sama dengan kemampuan intelektual dan psikomotorik; (2) sekolah merupakan bagian dari masyarakat yang memberikan pengalaman belajar terencana dimana peserta didik menerapkan apa yang dipelajari di sekolah ke masyarakat dan memanfaatkan masyarakat sebagai sumber belajar; mengembangkan sikap, pengetahuan, dan keterampilan serta menerapkannya dalam berbagai situasi di sekolah dan masyarakat; memberi waktu yang cukup leluasa untuk mengembangkan berbagai sikap, pengetahuan, dan keterampilan.

Kompetensi diartikan sebagai pengetahuan, keterampilan dan sikap nilai yang terwujud dalam kebiasaan berpikir dan bertindak. Kompetensi Dasar adalah: sejumlah kemampuan dasar yang harus dimiliki peserta didik dalam mata pelajaran tertentu sebagai rujukan untuk menyusun indikator kompetensi (Mulyasa, 2006). Kompetensi Dasar dikembangkan dari Kompetensi Inti, sedangkan pengembangan Kompetensi Inti mengacu pada Struktur Kurikulum. Kompetensi Inti merupakan kompetensi yang mengikat berbagai Kompetensi Dasar ke dalam aspek sikap, keterampilan, dan pengetahuan yang harus dipelajari peserta didik 
untuk suatu jenjang sekolah, kelas, dan mata pelajaran. Kompetensi Inti harus dimiliki peserta didik untuk setiap kelas melalui pembelajaran dengan pendekatan pembelajaran siswa aktif.

Ruang lingkup mata pelajaran Pendidikan Kewarganegaraan meliputi aspekaspek sebagai berikut: (1) Persatuan dan Kesatuan bangsa, meliputi: Hidup rukun dalam perbedaan, Cinta lingkungan, Kebanggaan sebagai bangsa Indonesia, Sumpah Pemuda, Keutuhan Negara Kesatuan Republik Indonesia, Partisipasi dalam pembelaan negara, Sikap positif terhadap Negara Kesatuan Republik Indonesia, Keterbukaan dan jaminan keadilan, (2) Norma, hukum dan peraturan, meliputi: Tertib dalam kehidupan keluarga, Tata tertib di sekolah, Norma yang berlaku di masyarakat, Peraturanperaturan daerah, Norma-norma dalam kehidupan berbangsa dan bernegara, Sistim hukum dan peradilan nasional, Hukum dan peradilan internasional, (3) Hak asasi manusia meliputi: Hak dan kewajiban anak, Hak dan kewajiban anggota masyarakat, Instrumen nasional dan internasional HAM, Pemajuan, penghormatan dan perlindungan HAM, (4) Kebutuhan warga negara meliputi: Hidup gotong royong, Harga diri sebagai warga masyarakat, Kebebasan berorganisasi, Kemerdekaan mengeluarkan pendapat, Menghargai keputusan bersama, Prestasi diri , Persamaan kedudukan warga Negara.

Menurut Martono (2005), bahan ajar berperan penting bagi guru dan siswa sebagai kenderaan untuk mencapai kompetensi. Bagi siswa bahan ajar akan berpengaruh terhadap kepribadaiannya, walaupun tidak sama antara satu siswa dengan siswa lainnya. Bahan ajar berfungsi sebagai masukan instrumental dalam proses pembelajaran.

Dengan bahan ajar yang baik, yang isinya mencakup Kompetensi Dasar (KD) sesuai dengan tuntutan standar isi, standar bahan ajar secara umum (penyajiannya menarik, bahasanya baku, illustasi tepat dan menarik) maka diharapkan proses pembelajaran yang dilakukan guru dan siswa mencapai hasil yang optimal. Beberapa faktor yang mempengaruhi kualitas bahan ajar, yaitu: (1) Sudut pandang; (2) Kejelasan konsep; (3) Relevan dengan kurikulum; (4) Menarik minat; (5) Membutuhkan motivasi; (6) Mentimulasi aktivitas siswa; (7) Ilustrasi; (8) Bahasanya sesuai dengan siswa; (9) Kalimatnya efektif; (10) Bahasa yang sopan, sederhana dan menarik; (13) Memantapkan nilai-nilai; (14) Selaras dan tidak bertentangan dengan Pancasila dan UUD 1945 serta peraturan perundang-undangan yang berlaku; dan (15) Tidak mengandung unsur yang dapat menimbulkan gangguan ketertiban yang berkaitan dengan suku, agama, dan ras (Mastutiningsih, 2003).

Pada dasarnya, sumber belajar yang dipakai dalam pendidikan atau pelatihan adalah suatu sistem yang terdiri dan sekumpulan bahan atau situasi yang diciptakan dengan sengaja dan dibuat agar siswa belajar secara individual. Menurut Mulyasa (2006), bahwa pada hakekatnya tidak ada satupun sumber belajar yang dapat memenuhi segala macam kebutuhan, oleh karena itu bicara sumber belajar perlu dipandang dalam arti luas, jamak dan beraneka ragam.

Menurut Martono (2005), ada beberapa peran sentral bahan ajar dalam memberdayakan siswa, yaitu : Bahan ajar dapat ditempatkan sebagai sumber informasi setelah guru, buku dapat menarik minat dan niat siswa untuk menguasai informasi dengan motivasi tinggi, bahan ajar dapat berperan sebagai manejer dalam kegiatan belajar siswa, bahan ajar dapat memenuhi tuntutan kurikulum dan memuat implementasi pesan kurikulum bahkan dapat melebihinya, bahan ajar dapat digunakan sebagai wacana untuk melatih daya nalar dan pembentukan sikap siswa untuk menghadai perubahan dunia yang relatif cepat., bahan ajar dapat memuat informasi yang essensial dan srtategis, bermanfaat sebagai alat pemecahan masalah dan bahan ajar dapat menyajikan informasi yang komunikatif, menarik dan tidak membosankan

Bahan ajar pelajaran merupakan salah satu sumber belajar dan media pembelajaran yang sangat penting untuk mendukung tercapainya kompetensi-kompetensi yang menjadi tujuan pembelajaran. Bahan ajar dapat menguatkan dan mendukung informasi materi yang disampaikan oleh guru dalam pembelajaran agar berkembang, mudah diingat dan dapat diulang-ulang agar informasi tersebut tumbuh dan berkembang sehingga mencapai kompetensi yang diinginkan (Metsala dan Glynn, 1996).

Bahan ajar dapat juga menjadi media pembelajaran yang sangat berarti apabila bahan ajar tersebut digunakan sebagai alat komunikasi untuk membawa informasi akurat dari sumber belajar kepada pembelajar. (Silitonga dan 
Situmorang, 2009). Media adalah segala sesuatu yang dapat digunakan untuk menyalurkan pesan dan dapat merangsang pikiran, membangkitkan semangat, perhatian dan kemauan siswa sehingga dapat mendorong terjadinya proses pembelajaran pada diri siswa. Bahan ajar adalah media komunikasi yang sangat tepat untuk menginformasikan ilmu, tekhnologi, seni, agama dan ide-ide. Bahan ajar sebagai media pendidikan sangat diperlukan dalam pembelajaran karena akan dapat menjelaskan berbagai fenomena yang sulit, termasuk konsep yang abstrak menjadi pengetahuan yang realistis (Souhwick, 2007). Agar bahan ajar dapat efektif menunjang pencapaian kompetensi dan bermakna terhadap prestasi belajar, maka bahan ajar harus memenuhi standar mutu.

Yamin (2009), bahan ajar sangat efektif sebagai media pembelajaran karena : penyampaian materi pelajaran dapat diseragamkan, proses pembelajaran menjadi lebih menarik dan interaktif, Jumlah waktu belajar-mengajar dapat dikurangi, kualitas belajar siswa dapat ditingkatkan, proses belajar dapat dilakukan dimana dan kapan saja, sikap positif siswa terhadap bahan pelajaran maupun terhadap proses belajar dapat ditingkatkan, peran guru dapat berubah kearah yang lebih positif dan produktif

Materi pembelajaran (instructional materials) adalah pengetahuan, keterampilan, dan sikap yang harus dipelajari siswa dalam rangka mencapai standar kompetensi yang telah ditentukan. Secara terperinci, jenis-jenis materi pembelajaran terdiri dari pengetahuan (fakta, konsep, prinsip, prosedur), keterampilan, dan sikap atau nilai (Sudrajat, 2009).

Menurut Wibowo (2005), ada empat aspek yang harus diperhatikan dalam pengukuran kualitas buku pelajaran, yaitu : (1) Aspek materi pelajaran. Materi pelajaran merupakan bahan pelajaran yang disajikan dalam buku pelajaran yang harus memperhatikan relevansi, edukasi, keakuratan dan proposionalitas. Isi materi pelajaran harus sesuai dan relevan dengan tuntutan kurikulum yang berlaku, dengan kompetensi yang harus dimiliki oleh lulusan tingkat pendidikan tertentu, dengan tingkat perkembangan serta karakteristik siswa yang menggunakan bahan ajar tersebut. Kecukupan mengandung arti bahwa muatan materi harus memadai dalam rangka mencapai kompetensi, tidak kurang dan tidak berlebihan. Keakuratan diartikan bahwa isi materi yang disajikan benar secara keilmuan, mutakhir (sesuai dengan hakekat pengetahuan). Porposionalitas dimaksudkan bahwa uraian materinya memenuhi keseimbangan kelengkapan, kedalaman dan seimbang antara materi pokok dengan materi pendukungnya., (2) Aspek penyajian. Penyajian harus lengkap, sistematis, kesesuaian sajian dengan tuntutan pembelajaran yang berpusat pada siswa dan cara penyajian yang membuat enak dibaca dan dipelajari serta menumbuhkan minat dan niat siswa untuk mempelajarinya, (3) Aspek Bahasa dan keterbacaan. Bahasa adalah sarana penyampaian dan penyajian bahan, seperti kosakata, kalimat, paragraf dan wacana, sedangkan keterbacaan berkaitan dengan tingkat kemudahan bahasa bagi tingkatan siswa, (4) Aspek grafika. Grafika berkenaan dengan fisik buku, yang meliputi ukuran buku, jenis kertas, cetakan, ukuran huruf, warna dan illustrasi yang membuat siswa menyenangi, meminati untuk membacanya.

Rumusan masalah penelitian dan pengembangan ini adalah: (1) Bagaimana urutan materi pelajaran PPKn yang layak dan tepat untuk diajarkan di SMA kelas X agar sistematis dan mudah dipahami oleh siswa yang memenuhi Kompetensi Inti (KI) dan Kompetensi Dasar (KD) sesuai dengan kurikulum 2013?; (2) Bagaimana desain bahan ajar PPKn SMA kelas $\mathrm{X}$ yang efektif agar dapat membantu siswa dalam mengoptimalkan hasil belajarnya?

\section{METODE}

Penelitian ini dilaksanakan di Kabupaten Aceh Tamiang, dengan memilih SMA Negeri 1 Kejuruan Muda. Populasi merupakan keseluruhan dari unsur-unsur yang akan diteliti. Populasi dalam penelitian ini adalah seluruh siswa kelas X. Sampel penelitian diambil secara acak 2 kelas, yang melakukan uji coba bahan ajar hasil pengembangan. Validator dalam penelitian ini adalah validator ahli (dosen) dan validator pengguna yaitu guru PPKn SMA, yang mengajar di kelas X SMA atau guru PPKn yang mempunyai pengalaman mengajar SMA di kelas $\mathrm{X}$ serta memiliki jenjang pendidikan akademis minimal S1 PPKn.

Penelitian ini merupakan penelitian R \& $\mathrm{D}$ (Research and Development) yang merujuk pada langkah-langkah penelitian pengembangan model Borg and Gall (1983), pengembangan bahan ajar merujuk pada Dick and Carey. Pada tahap analisis, kegiatan yang dilakukan berupa 
analisis beberapa aspek pembelajaran yang akan dicapai sesuai dengan materi pembelajaran. analisis aspek tersebut dibagi menjadi 5 tahap, yaitu : melakukan studi pendahuluan, mengidentifikasi kebutuhan, analisis pembelajaran, melakukan studi pendahuluan, mengidentifikasi kebutuhan sesuai acuan kurikulum 2013, dan analisis pembelajaran sesuai KI dan KD mata pelajaran PPKn SMA Kelas X,

Tahap berikutnya adalah tahap pengembangan bahan ajar. Tujuan dari tahap pengembangan adalah mengembangkan materi pembelajaran berupa rancangan awal bahan ajar, dengan penyempurnaan berdasarkan serangkaian kegiatan yang terstruktur dan sistematis, sehingga dihasilkan bahan ajar PPKn yang layak digunakan dalam pembelajaran PPKn. Pada tahap pengembangan ini terdiri dari beberapa kegiatan, yakni : (1) validasi bahan ajar oleh dosen (validator ahli) dan pengajar (guru) PPKn SMA dilanjutkan dengan revisi, (3) uji coba terbatas pada 64 siswa, (4) analisis data, serta (5) penulisan laporan.

Angket penilaian dari validator menggunakan instrument dari BSNP menggunakan skala Likert dengan kategori sebagai berikut :

Angka 1 berarti sangat tidak setuju ( skor 1 )

Angka 2 berarti tidak setuju ( skor 2 )

Angka 3 berarti setuju ( skor 3 )

Angka 4 berarti sangat setuju ( skor 4 )

Penentuan tentang validitas diketahui melalui rentang skor tertinggi dikurangi skor terendah dibagi dengan skor tertinggi. Rentang kriteria validitas analisis nilai rata-rata yang di gunakan dapat di lihat pada tabel 3.1. Skala penilaian yang digunakan adalah 1 sebagai skor terendah dan 4 sebagai skor tertinggi

Tabel 3.1 Rentang validitas analisis nilai ratarata hasil perhitungan berdasarkan penilaian validator terhadap materi pengembangan bahan ajar pelajaran PPKn

\begin{tabular}{|c|l|}
\hline Rata - rata & \multicolumn{1}{|c|}{ Kriteria validasi } \\
\hline $3,26-4,00$ & Valid dan tidak perlu revisi \\
\hline $2,51-3,25$ & $\begin{array}{l}\text { Cukup valid dan tidak perlu } \\
\text { revisi }\end{array}$ \\
\hline $1,76-2,50$ & $\begin{array}{l}\text { Kurang valid, sebagian isi } \\
\text { buku perlu di revisi }\end{array}$ \\
\hline $1,00-1,75$ & $\begin{array}{l}\text { Tidak valid dan perlu revisi } \\
\text { total }\end{array}$ \\
\hline
\end{tabular}

Hasil perhitungan rentang validitas disesuaikan dengan angka kesepakatan dan dapat ditentukan dengan rumus :

Rata-rata

$\underline{\sum \text { (Skor } x \text { Jumlah val idator) }}$

Jumlah val idator

Rentangan validasi dari angka tersebut dan sekaligus menarik kesimpulan dari hasil. Untuk menganalisis data kualitatif dilakukan dengan menggunakan tingkat persentase kesepakatan dalam mengambil kesimpulan, sedangkan untuk melihat efektivitas bahan ajar pembelajaran PPKn dilakukan langkah-langkah sebagai berikut:

1. Mentabulasi hasil tes belajar siswa

2. Mencari nilai rata-rata, standar deviasi, varians, median, modus, dan membuat distribusi frekwensi data hasil belajar siswa. Melakukan uji-t untuk melihat signifikansi perbedaan hasil belajar siswa pada taraf signifikansi 5\%.

3. Untuk pengujian hipotesis penelitian ini dilakukan dengan menggunakan rumus uji-t

$$
\begin{array}{r}
\text { thitung } \begin{array}{r}
=\frac{x_{1}-\overline{x_{2}}}{S} \\
\sqrt[S]{\frac{1}{n_{1}}+\frac{1}{n_{2}}} \\
\text { dengan }
\end{array} \\
\mathrm{S}^{2} \quad=\frac{\left(n_{1}-1\right) S_{1}^{2}+\left(n_{2}-1\right) S_{2}^{2}}{n_{1}+}
\end{array}
$$

HASIL DAN PEMBAHASAN

\begin{tabular}{|c|c|c|c|c|c|c|}
\hline \multirow[t]{2}{*}{ Kelayakan Isi } & \multirow[t]{2}{*}{ Komponen } & \multicolumn{4}{|c|}{ Tanggapan } & \multirow{2}{*}{$\begin{array}{l}\text { Rentang } \\
\text { Validasi }\end{array}$} \\
\hline & & 1 & 2 & 3 & 4 & \\
\hline \multirow[t]{5}{*}{ Cakupan Materi } & Kelengkapan kompetensi & - & - & - & $\sqrt{ }$ & \multirow{4}{*}{3,75} \\
\hline & Keluasan materi & - & - & - & $\sqrt{ }$ & \\
\hline & Kedalaman materi & - & - & $\sqrt{ }$ & - & \\
\hline & Penjelasan kompetensi inti & - & - & - & $\sqrt{ }$ & \\
\hline & Akurasi fakta & - & - & - & $\sqrt{ }$ & 3,80 \\
\hline
\end{tabular}

Hasil

Tabel 1. Penilaian bahan ajar PPKn berdasarkan Kelayakan Isi oleh validator ahli 


\begin{tabular}{|c|c|c|c|c|c|c|}
\hline \multirow{4}{*}{$\begin{array}{c}\text { Akurasi } \\
\text { Materi }\end{array}$} & Akurasi konsep & - & - & - & $\sqrt{ }$ & \\
\hline & Akurasi prinsip/hukum & - & - & - & $\sqrt{ }$ & \\
\hline & Akurasi prosedur/metode & - & - & - & $\sqrt{ }$ & \\
\hline & Akurasi teori & - & - & $\sqrt{ }$ & - & \\
\hline \multirow{3}{*}{ Kemuktahiran } & Kesesuaian dengan perkembangan ilmu & - & - & - & $\sqrt{1}$ & \multirow{3}{*}{3,67} \\
\hline & Keterkinian/ketermasaan fitur (contoh-contoh) & - & - & & $\sqrt{ }$ & \\
\hline & Kutipan termasa (up to date) & - & - & $\sqrt{ }$ & - & \\
\hline \multirow{5}{*}{$\begin{array}{l}\text { Wawasan } \\
\text { Produktivitas }\end{array}$} & Menumbuhkan sikap spritual & - & - & - & $\sqrt{1}$ & \multirow{5}{*}{3,80} \\
\hline & Menumbuhkan etos kerja & - & - & - & $\sqrt{1}$ & \\
\hline & $\begin{array}{l}\text { Menumbuhkan semangat inovasi, kreativitas, } \\
\text { dan berpikir kritis }\end{array}$ & - & - & - & $\sqrt{ }$ & \\
\hline & Menumbuhkan sikap sosial & - & - & - & $\sqrt{ }$ & \\
\hline & Menumbuhkan daya saing & - & - & $\sqrt{ }$ & - & \\
\hline \multirow[b]{2}{*}{ Keingintahuan } & Menumbuhkan rasa ingin tahu & - & - & - & $\sqrt{ }$ & \multirow{2}{*}{4,00} \\
\hline & Memberi tantangan untuk belajar lebih jauh & - & - & - & $\sqrt{1}$ & \\
\hline \multirow{4}{*}{$\begin{array}{l}\text { Kecakapan } \\
\text { Hidup } \\
\text { (life skills) }\end{array}$} & Mengembangkan kecakapan personal & - & - & - & $\sqrt{1}$ & \multirow{4}{*}{4,00} \\
\hline & Mengembangkan kecakapan social & - & - & - & $\sqrt{ }$ & \\
\hline & Mengembangkan kecakapan akademik & - & - & - & $\sqrt{ }$ & \\
\hline & Mengembangkan kecakapan vokasional & - & - & - & $\sqrt{1}$ & \\
\hline \multirow{2}{*}{\begin{tabular}{l}
\multicolumn{1}{c}{ Wawasan } \\
keindonesian dan \\
Kontekstual
\end{tabular}} & Apresiasi terhadap kekayaan potensi Indonesia & - & - & - & $\sqrt{1}$ & \multirow[b]{2}{*}{3,5} \\
\hline & $\begin{array}{l}\text { Menyajikan contoh-contoh konkret dari } \\
\text { lingkungan lokal, nasional, regional, dan } \\
\text { internasional. }\end{array}$ & - & - & $\sqrt{ }$ & - & \\
\hline \multirow{2}{*}{$\begin{array}{l}\text { Kontektualisasi } \\
\text { pengembangan } \\
\text { wawasan } \\
\text { kompetensi }\end{array}$} & $\begin{array}{l}\text { Menyajikan struktur sosial dalam berbagai } \\
\text { kehidupan masyarakat }\end{array}$ & - & - & - & $\sqrt{ }$ & \multirow{2}{*}{3,5} \\
\hline & Mengembangkan nilai keadi;lan SARA & - & - & $\sqrt{ }$ & - & \\
\hline \multicolumn{6}{|c|}{ Rata-rata } & 3,75 \\
\hline
\end{tabular}

Rentang validasi bahan ajar PPKn hasil pengembangan berdasarkan standar kelayakan penyajian menurut validator ahli disajikan pada tabel 2 .

Tabel 2. Penilaian bahan ajar PPKn berdasarkan Kelayakan Penyajian oleh validator ahli

\begin{tabular}{|c|c|c|c|c|c|c|}
\hline \multirow{2}{*}{$\begin{array}{l}\text { Kelayakan } \\
\text { Penyajian }\end{array}$} & \multirow[t]{2}{*}{ Komponen } & \multicolumn{4}{|c|}{ Tanggapan } & \multirow{2}{*}{$\begin{array}{l}\text { Rentang } \\
\text { Validasi }\end{array}$} \\
\hline & & 1 & 2 & 3 & 4 & \\
\hline \multirow{7}{*}{$\begin{array}{l}\text { Teknik } \\
\text { Penyajian }\end{array}$} & Konsistensi sistematika sajian dalam bab & - & - & - & $\sqrt{1}$ & \multirow{7}{*}{3,63} \\
\hline & Kelogisan penyajian & - & - & - & $\sqrt{ }$ & \\
\hline & $\begin{array}{l}\text { Hubungan antar fakta, antar konsep dan antar } \\
\text { prinsip serta antar teori }\end{array}$ & - & - & $\sqrt{ }$ & - & \\
\hline & $\begin{array}{l}\text { Keseimbangan antar bab dan keseimbangan } \\
\text { substansi antar subbab dalam bab }\end{array}$ & - & - & - & $\sqrt{ }$ & \\
\hline & $\begin{array}{l}\text { Kesesuaian/ketepatan ilustrasi dengan materi dalam } \\
\text { bab }\end{array}$ & - & - & $\sqrt{ }$ & - & \\
\hline & $\begin{array}{l}\text { Penyajian tabel, gambar dan lampiran harus disertai } \\
\text { dengan rujukan termasa }\end{array}$ & - & - & - & $\sqrt{ }$ & \\
\hline & Identitas tabel, gambar dan lampiran & - & - & $\sqrt{ }$ & - & \\
\hline \multirow{6}{*}{$\begin{array}{l}\text { Pendukung } \\
\text { penyajian } \\
\text { Materi }\end{array}$} & Pengantar & - & - & - & $\sqrt{1}$ & \multirow{6}{*}{3,50} \\
\hline & Glosarium & - & - & - & $\sqrt{1}$ & \\
\hline & Daftar pustaka & - & - & $\sqrt{ }$ & - & \\
\hline & Indeks & - & - & - & $\sqrt{1}$ & \\
\hline & Kunci jawaban setiap akhir bab & - & $\sqrt{ }$ & - & - & \\
\hline & Ringkasan setiap akhir bab & - & - & - & $\sqrt{ }$ & \\
\hline
\end{tabular}




\begin{tabular}{|c|c|c|c|c|c|c|}
\hline \multirow{6}{*}{$\begin{array}{l}\text { Penyajian } \\
\text { pembelajara } \\
n\end{array}$} & Berpusat pada peserta didik & - & - & $\sqrt{ }$ & - & \multirow[t]{2}{*}{3,67} \\
\hline & Keterlibatan peserta didik & - & - & $\sqrt{ }$ & - & \\
\hline & Keterjalinan komunikasi interaktif & - & - & $\sqrt{ }$ & - & \multirow{4}{*}{3,17} \\
\hline & Kesesuaian dengan karakteristik mata pelajaran & - & - & - & $\sqrt{ }$ & \\
\hline & $\begin{array}{l}\text { Kemampuan merangsang kedalaman berpikir } \\
\text { peserta didik }\end{array}$ & - & - & $\sqrt{ }$ & - & \\
\hline & $\begin{array}{l}\text { Kemampuan memunculkan umpan balik untuk } \\
\text { evaluasi diri }\end{array}$ & - & - & $\sqrt{ }$ & - & \\
\hline
\end{tabular}

\section{Deskripsi data hasil validasi Menurut Pengguna (Guru)}

Pada penelitian ini, bahan ajar pelajaran PPKn yang telah dikembangkan, dinilai oleh pengguna (guru). responden guru yang dimaksud adalah enam orang guru PPKn sebagai pemakai produk yang mengajar di kelas X. Penilaian standar kelayakan isi dimulai dari cakupan materi, akurasi materi, kemutakhiran, wawasan produktivitas, keingintahuan, kecakapan hidup, mengembangkan wawasan keindonesian dan kontektual, serta kontekstualisasi pengembangan wawasan kompetensi.

Tabel 3. Penilaian Bahan ajar PPKn Berdasarkan Kelayakan Isi BSNP Menurut Responden Guru.

\begin{tabular}{|c|c|c|c|c|c|c|}
\hline \multirow[t]{2}{*}{ Kelayakan Isi } & \multirow[t]{2}{*}{ Komponen } & \multicolumn{4}{|c|}{ Tanggapan } & \multirow{2}{*}{$\begin{array}{l}\text { Rentang } \\
\text { Validasi }\end{array}$} \\
\hline & & 1 & 2 & 3 & 4 & \\
\hline \multirow{3}{*}{ Cakupan Materi } & Kelengkapan Kompetensi & - & - & 1 & 5 & 3,8 \\
\hline & Keluasan materi & - & - & 1 & 5 & 3,8 \\
\hline & Kedalaman materi & & & 1 & 5 & 3,8 \\
\hline \multirow{5}{*}{$\begin{array}{c}\text { Akurasi } \\
\text { Materi }\end{array}$} & Akurasi fakta & - & - & - & 6 & 4,0 \\
\hline & Akurasi konsep & - & - & 3 & 3 & 3,5 \\
\hline & Akurasi prinsip/hukum & - & - & 2 & 4 & 3,6 \\
\hline & Akurasi prosedur/metode & - & - & 1 & 5 & 3,8 \\
\hline & Akurasi teori & - & - & 2 & 4 & 3,6 \\
\hline \multirow{3}{*}{ Kemuktahiran } & Kesesuaian dengan perkembangan ilmu & - & - & 2 & 4 & 3,6 \\
\hline & $\begin{array}{l}\text { Keterkinian/ketermasaan } \\
\text { contoh) }\end{array}$ & - & - & 2 & 4 & 3,6 \\
\hline & Kutipan termasa (up to date) & - & - & 3 & 3 & 3,5 \\
\hline \multirow{4}{*}{$\begin{array}{c}\text { Wawasan } \\
\text { Produktivitas }\end{array}$} & Menumbuhkan semangat kewirausahaan & - & - & 4 & 2 & 3,3 \\
\hline & Menumbuhkan etos kerja & - & - & 2 & 4 & 3,6 \\
\hline & $\begin{array}{l}\text { Menumbuhkan semangat inovasi, kreativitas, } \\
\text { dan berpikir kritis }\end{array}$ & - & - & 1 & 5 & 3,8 \\
\hline & Menumbuhkan daya saing & - & - & 2 & 4 & 3,6 \\
\hline \multirow[b]{2}{*}{ Keingintahuan } & Menumbuhkan rasa ingin tahu & - & - & 3 & 3 & 3,5 \\
\hline & Memberi tantangan untuk belajar lebih jauh & - & - & 2 & 4 & 3,6 \\
\hline \multirow{4}{*}{$\begin{array}{l}\text { Kecakapan } \\
\text { Hidup } \\
\text { (life skills) }\end{array}$} & Mengembangkan kecakapan personal & - & - & 4 & 2 & 3,3 \\
\hline & Mengembangkan kecakapan social & - & - & 2 & 4 & 3,6 \\
\hline & Mengembangkan kecakapan akademik & - & - & 2 & 4 & 3,6 \\
\hline & Mengembangkan kecakapan vokasional & - & - & 4 & 2 & 3,3 \\
\hline \multirow{4}{*}{ Kontekstual } & $\begin{array}{llll}\text { Apresiasi } & \text { terhadap } & \text { kekayaan } & \text { potensi } \\
\text { Indonesia } & & & \\
\end{array}$ & - & 1 & 3 & 2 & 3,1 \\
\hline & $\begin{array}{l}\text { Menyajikan contoh-contoh konkret dari } \\
\text { lingkungan lokal, nasional, regional, dan } \\
\text { internasional. }\end{array}$ & - & 1 & 4 & 1 & 3,0 \\
\hline & $\begin{array}{l}\text { Menumbuhkan struktur sosial dalam berbagai } \\
\text { kehidupan masyarakat }\end{array}$ & - & - & 2 & 4 & 3,6 \\
\hline & Mengembangkan nilai keadilan dan SARA & - & - & 2 & 4 & 3,6 \\
\hline \multicolumn{6}{|c|}{ Rata-rata } & 3,59 \\
\hline
\end{tabular}




\section{Penilaian Bahan Ajar PPKn Berdasarkan Standar Kelayakan Bahasa}

Penilaian berdasarkan standar kelayakan bahasa dilakukan dengan memberikan tanda checklist $(\sqrt{ })$ pada setiap skor. Skor urutan penilaian adalah $1=$ sangat tidak setuju, 2 = tidak setuju, 3 = setuju, 4 = sangat setuju. Penilaian bahan ajar berdasarkan kelayakan bahasa terdiri beberapa sub komponen penilaian, yaitu kesesuaian dengan perkembangan peserta didik, komunikatif, dialog dan interaktif, lugas, koherensi dan keruntutan alur pikir, kesesuaian dengan kaidah Bahasa Indonesia yang benar dan penggunaan istilah dan simbol/lambang.

Tabel 4. Penilaian bahan ajar pelajaran PPKn Berdasarkan Kelayakan Bahasa menurut guru.

\begin{tabular}{|c|c|c|c|c|c|c|}
\hline \multirow{2}{*}{$\begin{array}{l}\text { Kelayakan } \\
\text { Bahasa }\end{array}$} & \multirow[t]{2}{*}{ Komponen } & \multicolumn{4}{|c|}{ Tanggapan } & \multirow{2}{*}{$\begin{array}{l}\text { Rentang } \\
\text { Validasi }\end{array}$} \\
\hline & & 1 & 2 & 3 & 4 & \\
\hline \multirow{2}{*}{$\begin{array}{l}\text { Kesesuaian dengan } \\
\text { perkembangan } \\
\text { peserta didik }\end{array}$} & $\begin{array}{l}\text { Kesesuaian dengan tingkat perkembangan } \\
\text { berpikir peserta didik }\end{array}$ & - & - & 2 & 4 & 3,6 \\
\hline & $\begin{array}{l}\text { Kesesuaian dengan tingkat perkembangan } \\
\text { emosional peserta didik }\end{array}$ & - & - & 1 & 5 & 3,8 \\
\hline \multirow[t]{2}{*}{ Komunikatif } & Keterpahaman peserta didik terhadap pesan & - & - & 2 & 4 & 3,6 \\
\hline & Kesesuaian ilustrasi dengan substansi pesan & - & 1 & 2 & 3 & 3,3 \\
\hline \multirow{2}{*}{$\begin{array}{l}\text { Dialog dan } \\
\text { interaktif }\end{array}$} & $\begin{array}{l}\text { Kemampuan memotivasi peserta didik } \\
\text { untuk merespon pesan }\end{array}$ & - & - & 2 & 4 & 3,6 \\
\hline & Dorongan berpikir kritis & - & 1 & 1 & 4 & 3,5 \\
\hline \multirow[t]{2}{*}{ Lugas } & Ketepatan struktur kalimat & - & - & 2 & 4 & 3,6 \\
\hline & Kebakuan istilah & - & 1 & 1 & 4 & 3,5 \\
\hline \multirow{3}{*}{$\begin{array}{l}\text { Koherensi dan } \\
\text { keruntutan alur } \\
\text { pikir }\end{array}$} & $\begin{array}{l}\text { Ketepatan antar bab, antar sub bab dan antar } \\
\text { sub bab dalam bab, dan antar alinea dalam } \\
\text { sub bab }\end{array}$ & - & - & 3 & 3 & 3,5 \\
\hline & Keterkaitan antar kalimat dalam satu alinea & - & - & - & 6 & 4,0 \\
\hline & $\begin{array}{l}\text { Keutuhan makna dalam bab, dalam sub bab } \\
\text { dan makna dalam satu alinea }\end{array}$ & - & - & 1 & 5 & 3,8 \\
\hline \multirow{2}{*}{$\begin{array}{l}\text { Kesesuaian dengan } \\
\text { kaidah Bahasa } \\
\text { Indonesia }\end{array}$} & Ketepatan tata bahasa & - & - & 2 & 4 & 3,6 \\
\hline & Ketepatan ejaan & - & - & 3 & 3 & 3,5 \\
\hline \multirow{2}{*}{$\begin{array}{l}\text { Penggunaan istilah } \\
\text { simbol/lambang }\end{array}$} & Konsistensi penggunaan istilah & - & - & 1 & 5 & 3,8 \\
\hline & Konsistensi penggunaan simbol / lambang & - & - & 3 & 3 & 3,5 \\
\hline & Rata-rata & & & & & 3,6 \\
\hline
\end{tabular}

\section{Penilaian Bahan Ajar Pelajaran PPKn Berdasarkan Standar Kelayakan Penyajian}

Penilaian berdasarkan standar kelayakan penyajian dilakukan dengan memberikan tanda checklist $(\sqrt{ })$ pada setiap skor. Skor urutan penilaian adalah $1=$ sangat tidak setuju, $2=$ tidak setuju, 3 = setuju, 4 = sangat setuju. Penilaian buku berdasarkan kelayakan penyajian terdiri beberapa sub komponen penilaian, yaitu teknik penyajian, pendukung penyajian materi, penyajian pembelajaran.

Pada sub komponen teknik penyajian terdapat butir-butir penilaian antara lain: konsistensi sistematika sajian dalam bab; kelogisan penyajian; keruntutan konsep; hubungan antar fakta, antar konsep, antar prinsip serta antar teori; keseimbangan antar bab dan keseimbangan substansi antar sub bab dalam bab; kesesuaian/ketepatan ilustrasi dengan materi dalam bab; penyajian tabel, gambar, dan lampiran harus disertai dengan rujukan termasa; identitas tabel, gambar, dan lampiran.

Tabel 5. Penilaian bahan ajar pelajaran PPKn berdasarkan Standar Komponen Kelayakan Penyajian BSNP menurut responden guru

\begin{tabular}{|l|l|c|c|c|c|c|}
\hline Kelayakan & Komponen & \multicolumn{3}{|c|}{ Tanggapan } & \multirow{2}{*}{ Validasi } \\
\cline { 3 - 6 } Penyajian & & $\mathbf{1}$ & $\mathbf{2}$ & $\mathbf{3}$ & $\mathbf{4}$ & \\
\hline & Konsistensi sistematika sajian & & & - & 6 & 4,0 \\
\cline { 2 - 6 } & Kelogisan penyajian & & & 2 & 4 & 3,6 \\
\hline
\end{tabular}




\begin{tabular}{|c|c|c|c|c|c|c|}
\hline \multirow{6}{*}{$\begin{array}{l}\text { Teknik } \\
\text { Penyajian }\end{array}$} & Keruntutan konsep & & & 2 & 4 & 3,6 \\
\hline & $\begin{array}{l}\text { Hubungan antara fakta, antar konsep dan antar } \\
\text { prinsip, serta antar teori }\end{array}$ & & 1 & 1 & 4 & 3,5 \\
\hline & $\begin{array}{l}\text { Keseimbangan antar bab dan keseimbangan } \\
\text { substansi antar sub bab dalam bab }\end{array}$ & & & 3 & 3 & 3,5 \\
\hline & $\begin{array}{l}\text { Kesesuaian/ketepatan ilustrasi dengan materi } \\
\text { dalam bab }\end{array}$ & & & 2 & 4 & 3,6 \\
\hline & $\begin{array}{l}\text { Penyajian tabel, gambar, dan lampiran harus } \\
\text { disertai dengan rujukan termasa }\end{array}$ & & 2 & 1 & 3 & 3,2 \\
\hline & Identitas tabel, gambar, dan lampiran & & 1 & 1 & 4 & 3,5 \\
\hline \multirow{6}{*}{$\begin{array}{l}\text { Pendukung } \\
\text { Penyajian } \\
\text { Materi }\end{array}$} & Pengantar & & & 2 & 4 & 3,6 \\
\hline & Lampiran: Glosarium & & 1 & - & 5 & 3,6 \\
\hline & Lampiran: Daftar pustaka & & & 1 & 5 & 3,8 \\
\hline & Lampiran: Indeks & & & 2 & 4 & 3,6 \\
\hline & Lampiran: Kunci jawaban di setiap akhir bab & 1 & 2 & 2 & 1 & 2,5 \\
\hline & Ringkasan di setiap akhir bab & & & 2 & 4 & 3,6 \\
\hline \multirow{7}{*}{$\begin{array}{l}\text { Penyajian } \\
\text { Pembelajara } \\
\text { n }\end{array}$} & Berpusat pada peserta didik & & & 2 & 4 & 3,6 \\
\hline & Keterlibatan peserta didik & & & 1 & 5 & 3,8 \\
\hline & Keterjalinan komunikasi interaktif & & & 2 & 4 & 3,6 \\
\hline & Kesesuaian dengan karakteristik mata pelajaran & & & 2 & 4 & 3,6 \\
\hline & $\begin{array}{l}\text { Kemampuan merangsang kedalaman berpikir } \\
\text { peserta didik }\end{array}$ & & & 2 & 4 & 3,6 \\
\hline & $\begin{array}{l}\text { Kemampuan memunculkan umpan balik untuk } \\
\text { evaluasi diri }\end{array}$ & & & 2 & 4 & 3,6 \\
\hline & Ringkasan di setiap akhir bab & & & 1 & 5 & 3,8 \\
\hline & Rata-rata & & & & & 3,56 \\
\hline
\end{tabular}

Rentang validasi secara keseluruhan yang diperoleh untuk bahan ajar PPKn SMA kelas X sesuai kurikulum 2013 ini berarti berada pada kisaran rata-rata 3,26-4,00 yang berarti bahan ajar PPKn yang dikembangkan dinyatakan valid dan tidak perlu revisi.

Tabel 6. Rentang Validasi Akhir bahan ajar PPKn

\begin{tabular}{|c|c|}
\hline $\begin{array}{c}\text { Komponen Penilaian } \\
\text { Buku Pelajaran }\end{array}$ & $\begin{array}{c}\text { Rata-Rata Rentang Validasi } \\
\text { Komponen }\end{array}$ \\
\hline Kelayakan Isi & 3,59 \\
\hline Kelayakan Bahasa & 3,60 \\
\hline Kelayakan Penyajian & 3,56 \\
\hline Rata-rata & $\mathbf{3 , 5 8}$ \\
\hline
\end{tabular}

\section{Hasil Uji Coba Tahap IV/ Uji Coba Lapangan}

Hasil uji coba lapangan akan dijadikan data untuk mengukur kelayakan Isi dari produk yang dikembangkan, sekaligus untuk mengetahui sampai sejauh mana manfaat produk tersebut bagi peserta didik dalam proses belajar mengajar. Hasil evaluasi terhadap bahan ajar pada aspek kualitas materi pembelajaran sesuai kriteria kelayakan dari BSNP berdasarkan ujicoba lapangan dapat dilihat pada tabel pada tabel 7 .

Tabel 7. Penilaian bahan ajar pelajaran PPKn Berdasarkan Standar Komponen Kelayakan Isi BSNP pada Ujicoba Lapangan.

\begin{tabular}{|c|l|c|c|c|c|c|}
\hline Kelayak & Komponen & \multicolumn{4}{|c|}{ Tanggapan } & Rentang \\
an Isi & & $\mathbf{1}$ & $\mathbf{2}$ & $\mathbf{3}$ & $\mathbf{4}$ & Validasi \\
\hline Cakupan & Kelengkapan Kompetensi & - & - & 3 & 29 & 3,9 \\
\cline { 2 - 7 } Materi & Keluasan materi & 2 & 5 & 20 & 5 & 2,9 \\
\hline
\end{tabular}




\begin{tabular}{|c|c|c|c|c|c|c|}
\hline & Kedalaman materi & - & - & 25 & 7 & 3,3 \\
\hline \multirow{5}{*}{$\begin{array}{c}\text { Akurasi } \\
\text { Materi }\end{array}$} & Akurasi fakta & - & 6 & 18 & 8 & 3,1 \\
\hline & Akurasi konsep & - & - & 2 & 30 & 3,9 \\
\hline & Akurasi prinsip/hukum & - & - & 16 & 16 & 3,5 \\
\hline & Akurasi prosedur/metode & - & 1 & 30 & 1 & 3,0 \\
\hline & Akurasi teori & - & - & 2 & 30 & 3,9 \\
\hline \multirow{3}{*}{$\begin{array}{l}\text { Kemutah } \\
\text { iran }\end{array}$} & Kesesuaian dengan perkembangan ilmu & - & 2 & 2 & 28 & 3,8 \\
\hline & $\begin{array}{l}\text { Keterkinian/ketermasaan fitur (contoh- } \\
\text { contoh) }\end{array}$ & - & 13 & 14 & 5 & 3,75 \\
\hline & Kutipan termasa (up to date) & - & - & 11 & 21 & 3,66 \\
\hline \multirow{4}{*}{$\begin{array}{l}\text { Wawas } \\
\text { an } \\
\text { Produkti } \\
\text { vitas }\end{array}$} & Menumbuhkan semangat kewirausahaan & - & 12 & 18 & 2 & 2,7 \\
\hline & Menumbuhkan etos kerja & - & 15 & 9 & 8 & 2,8 \\
\hline & $\begin{array}{lr}\text { Menumbuhkan semangat } & \text { inovasi, } \\
\text { kreativitas, dan berpikir kritis } & \end{array}$ & - & 10 & 20 & 2 & 2,75 \\
\hline & Menumbuhkan daya saing & - & - & 11 & 21 & 3,66 \\
\hline \multirow[b]{2}{*}{$\begin{array}{c}\text { Keingin } \\
\text { tahuan }\end{array}$} & Menumbuhkan rasa ingin tahu & - & - & 3 & 29 & 3,9 \\
\hline & $\begin{array}{l}\text { Memberi tantangan untuk belajar lebih } \\
\text { jauh }\end{array}$ & - & - & 1 & 31 & 3,97 \\
\hline \multirow{4}{*}{$\begin{array}{c}\text { Kecakap } \\
\text { an Hidup } \\
\text { (life } \\
\text { skills) }\end{array}$} & Mengembangkan kecakapan personal & - & - & 12 & 20 & 3,6 \\
\hline & Mengembangkan kecakapan social & - & - & 12 & 20 & 3,6 \\
\hline & Mengembangkan kecakapan akademik & - & 3 & 12 & 15 & 3,2 \\
\hline & Mengembangkan kecakapan vokasional & - & - & - & 32 & 4,0 \\
\hline \multirow{4}{*}{$\begin{array}{l}\text { Kontekst } \\
\text { ual }\end{array}$} & $\begin{array}{l}\text { Apresiasi terhadap kekayaan potensi } \\
\text { Indonesia }\end{array}$ & - & - & 30 & 2 & 3,06 \\
\hline & $\begin{array}{l}\text { Menyajikan contoh-contoh konkret dari } \\
\text { lingkungan lokal, nasional, regional, dan } \\
\text { internasional. }\end{array}$ & - & - & 30 & 2 & 3,06 \\
\hline & $\begin{array}{l}\text { Menumbuhkan struktur sosial dalam } \\
\text { berbagai kehidupan masyarakat }\end{array}$ & - & - & 25 & 7 & 3,2 \\
\hline & $\begin{array}{l}\text { Mengembangkan nilai keadilan dan } \\
\text { SARA }\end{array}$ & - & - & 6 & 26 & 3,8 \\
\hline & Rata-rata & & & & & $\mathbf{3 , 4 0}$ \\
\hline
\end{tabular}

Efektifitas Bahan Ajar PPKn SMA Hasil Pengembangan

Bahan ajar PPKn yang telah dikembangkan dan divalidasi oleh validator ahli dan guru, berdasarkan hasil ujicoba perorangan, ujicoba kelompok kecil dan ujicoba lapangan dengan hasil bahan ajar tersebut telah valid dan tidak perlu revisi, maka selanjutnya dipilih satu bab dari bahan ajar PPKn untuk melihat keefektifitasan dari bajan ajar PPKn tersebut. Dari sebelas kelas yang ada di sekolah yang menjadi tempat sampel, maka diambil dua kelas untuk dijadikan kelas kontrol dan kelas eksperimen untuk mengetahui efektifitas dari bahan ajar PPKn. Dalam hal ini, keefektifitasan dilihat dari nilai pretest dan postest kelas yang dijadikan sampel untuk perlakuan. Dari hasil evalusi yang telah diperoleh, dilakukan pengujian normalitas dan homogenitas test. Uji Normalitas test terhadap kelas kontrol dan eksperimen dengan menggunakan program SPSS (Kolmogorove-Smirnove).

Berdasarkan hasil uji normalitas, homogenitas tersebut diperoleh bahwa kedua kelompok yaitu kelompok eksperimen dan kelompok kontrol berdistribusi normal dan memiliki varians yang homogen (sama) maka untuk mengetahui signifikansi perbedaan ratarata kedua kelompok data itu dihitung dengan uji t pada taraf signifikansi $\alpha=0,05$ dengan kriteria pengujian: Kriteria pengujiannya adalah tolak $\mathrm{H}_{0}$ jika $t_{\text {tabel }}<t_{\text {hitung }}$ dan terima $\mathrm{H}_{0}$ untuk kondisi lainnya dengan taraf signifikansi yang telah ditentukan 
Tabel 8. Group Statistics

\begin{tabular}{|ll|r|r|r|r|}
\hline \multicolumn{1}{|c|}{ Kelas } & \multicolumn{1}{c|}{ N } & \multicolumn{1}{c|}{ Mean } & \multicolumn{1}{c|}{ Std. Deviation } & Std. Error Mean \\
\hline Postes & Eksperimen & 30 & 80.67 & 10.681 & 1.950 \\
& Kontrol & 30 & 55.33 & 11.929 & 2.178 \\
\hline
\end{tabular}

Independent Samples Test

\begin{tabular}{|c|c|c|c|c|c|c|c|c|c|c|}
\hline & \multicolumn{2}{|c|}{$\begin{array}{c}\text { Levene's Test } \\
\text { for Equality } \\
\text { of Variances }\end{array}$} & \multicolumn{7}{|c|}{ t-test for Equality of Means } \\
\hline & & \multirow[b]{2}{*}{$\mathrm{F}$} & \multirow[b]{2}{*}{ Sig. } & \multirow[b]{2}{*}{$\mathrm{t}$} & \multirow[b]{2}{*}{ df } & \multirow[b]{2}{*}{$\begin{array}{c}\text { Sig. } \\
(2- \\
\text { tailed })\end{array}$} & \multirow[b]{2}{*}{$\begin{array}{c}\text { Mean } \\
\text { Difference }\end{array}$} & \multirow[b]{2}{*}{$\begin{array}{l}\text { Std. Error } \\
\text { Difference }\end{array}$} & \multicolumn{2}{|c|}{$\begin{array}{l}\text { 95\% Confidence } \\
\text { Interval of the } \\
\text { Difference }\end{array}$} \\
\hline & & & & & & & & & Lower & Upper \\
\hline & $\begin{array}{l}\text { Equal } \\
\text { variances } \\
\text { assumed }\end{array}$ & .649 & .424 & 8.666 & 58 & .000 & 25.333 & 2.923 & 19.481 & 31.185 \\
\hline tes & $\begin{array}{l}\text { Equal } \\
\text { variances not } \\
\text { assumed }\end{array}$ & & & 8.666 & $\begin{array}{r}57.3 \\
06\end{array}$ & .000 & 25.333 & 2.923 & 19.480 & 31.187 \\
\hline
\end{tabular}

Berdasarkan rata-rata prestasi belajar siswa diperoleh bahwa pembelajaran menggunakan bahan ajar PPKn hasil pengembangan dapat meningkatkan prestasi belajar siswa, yaitu dapat dilihat dari rata-rata nilai postest pada kelas eksperimen dibandingkan dengan kelas kontrol. Jumlah rata-rata keseluruhan pada kelas eksperimen diperoleh 80,667 dan rata-rata kelas kontrol 55,333. Hasil ini menyatakan bahwa penggunaan bahan ajar PPKn hasil pengembangan efektif untuk meningkatkan hasil belajar siswa pada pengajaran PPKn.

\section{PENUTUP}

Berdasarkan rumusan masalah, tujuan, hasil dan pembahasan penelitian pengembangan bahan ajar mata pelajaran PPKn SMA kelas X berbasis kurikulum 2013 yang dikemukakan sebelumnya maka dapat disimpulkan sebagai berikut:

1. Penelitian pengembangan ini mengacu pada model pengembangan Dick \& Carey (2005) dan untuk model pengembangan bahan ajar digunakan model pengembangan produk Borg \& Gall (2005). Oleh karena itu proses dan prosedur yang dilakukan dalam penelitian ini merupakan langkah dan proses yang melalui tahapan-tahapan, yaitu: validasi pengguna (guru), validasi ahli, uji coba terhadap calon pengguna bahan ajar dan dikembangkan berdasarkan hasil uji coba dan saran-saran perbaikan serta hasil temuan-temuan dilapangan. Oleh karena itu produk pengembangan bahan ajar yang dihasilkan merupakan hasil perbaikan dan pengembangan sesuai dengan kurikulum 2013 berdasarkan standar kelayakan dari BSNP dan kebutuhan pengguna dalam hal ini para peserta didik dan guru.

2. Rentang validasi yang diperoleh pada usulan materi PPKn adalah 3,5 berarti usulan materi dari bahan ajar PPKn yang diajukan layak digunakan dalam pengembangan bahan ajar pelajaran PPKn berbasis kurikulum 2013

3. Penilaian bahan ajar pelajaran PPKn berdasarkan empat kelayakan dari BSNP diperoleh rata-rata rentang validasi 3,54 Ini berarti bahwa, bahan ajar pelajaran PPKn berdasarkan standar kelayakan isi, bahasa, penyajian dn kegrafikan telah valid dan tidak perlu direvisi kembali.

4. Penggunaan bahan ajar pelajaran PPKn hasil pengembangan berbasis kurikulum 2013, efektif untuk meningkatkan hasil belajar siswa pada pengajaran PPKn. Hal ini dapat 
dilihat dari hasil perolehan rata-rata efektifitas pada kelas eksperimen yang menggunakan bahan ajar pelajaran PPKn hasil pengembangan, yaitu 80,667 lebih tinggi dibandingkan dengan rata-rata efektifitas pada kelas kontrol tanpa bahan ajar hasil pengembangan, yaitu 55,333.

\section{DAFTAR PUSTAKA}

Afrida, EY., (2012), Analisis Dan Standarisasi Buku Pelajaran Kimia Kelas XI SMK Sesuai KTSP Tesis. Medan; Program Pascasarjana Universitas Negeri Medan.

Akker J.V (1999). Principles and Methods of Development Research. Pada J. van den Akker, R.Branch, K. Gustafson, Nieven, dan T. Plomp (eds), Design Approaches and Tools in Education and Training (pp. 1-14). Dortrech: Kluwer Academic Publishers.

Angelina. (2010). Pengaruh Strategi Pembelajaran dan Gaya Belajar Terhadap Hasil Belajar Kimia Siswa SMA Swasta Gajah Mada Medan. Thesis. Medan: Program Pascasarjana Unimed.

Borg, W.R. \& Gall, M.D. Gall. (1983). Educational Research: An Introduction, Fifth Edition. New York: Longman.

Boyce, L.N., Van Tassel, J., Burrus, J.D., Sher, B.T., dan Jhonson, D.T., (1997), A Problem-Based Curriculum: Parallel Learning Opportunities for Student and Teacher, Journal of the Education of the Gifted 20: 363-366.

Dick, W. dan Carey, L. (1996). The Systematics Design Of Instruction. New York : Longman

Emzir., (2008), Metodologi Penelitian Pendidikan, Jakarta; PT. Raja Grafindo.

Gay, L.R. (1991). Educational Evaluation and Measurement: Com-petencies for Analysis and Application. Second edition. New York: Macmillan Publishing Compan.

Holliday, W.G., (2002), Selecting a Science Textbook, Science Scope 25 (4): 16-20.

Mastutiningsih, T. (2003). Keefektifan Kalimat Pada Wacana Buku Pelajaran Bahasa Indonesia Untuk Kelas I SLTP Terbitan Swasta (Studi Kasus Buku Pelajaran Bahasa Indonesia Terbitan Yudistira dan Erlangga). Skripsi. Semarang: Unnes
Mangal, S.K., (2002), Advanced Education Psychology, New Delhi; Prentice-Hall of India.

Martono, K., (2005.), Peranan Buku Dalam Proses Belajar Mengajar, (on line), hhtp//www:ganeca.blokspirit.com/archiv e. Diakses 20 Desember 2011.

Metsala, J.L., dan Glynn, S., (1996), Teaching with Analogies, Building on the science textbook, The Reading Teacher 49(6): 490.

Mulyasa, E., (2006), Kurikulum Berbasis Kompetensi. Konsep, Karakteristik, dan Implementasi. Bandung; Remaja Rosdakarya.

Mulyasa, E., (2013), Pengembangan dan Implementasi Kurikulum 2013. Bandung; Remaja Rosdakarya.

Napitupulu, S., (2007), Berbagai Pendekatan Dalam Belajar Mengajar, Jakarta; Bumi Aksara

Roestiyah. N. K., (1989), Strategi Belajar Mengajar, Jakarta; Bina Aksara.

Reigeluth. (1992). Instructional Design Strategies and Tacties. Educational Technology Publications. New Jersey: Englewood Cliffs.

Sanjaya, W., (2008), Strategi Pembelajaran Berorientasi Standar Proses Pendidikan, Ed. 1 Cet. 4, Jakarta; Kencana.

Santyasa, I Wayan. (2009). Metode Penelitian Pengembangan dan Teori Pengembangan Modul. Makalah disajikan dalam Pelatihan Bagi Para Guru TK, SD, SMP, SMA, dan SMK, Bali 12-14 Januari 2009. Singaraja: Universitas Pendidikan Ganesha.

Silitonga, L.L., dan Situmorang, M., (2009), Efektifitas Media Audiovisual Terhadap Peningkatan Prestasi Belajar Siswa pada Pengajaran Sistem Koloid. Jurnal Pendidikan Kimia. 1 (1): 45-51.

Sitepu, B.P., (2005), Memilih Buku Pelajaran, Jurnal Pendidikan Penabur. No.04/Th IV/Juli: 120.

Southwick, F.S., (2007), Theodore E. Woodward Award: Spare Me the Powerpoint and Bring Back the Medical Textbook, Trans Am Clin Climatol Assoc. 118: 116.

Supriadi, D., (2000), Anatomi Buku Sekolah Di Indonesia, Yogyakarta; adicita. 
Suriani, R., (2011), Analisis Dan Standarisasi Buku Pelajaran Kimia SMA kelas XI Semester 1 berdasarkan Kurikulum Tingkat Satuan Pendidikan, Tesis tidak diterbitkan, Medan; PPs Universitas Negeri Medan
Yamin, M., (2009), Desain Pembelajaran Berbasis Tingkat Satuan Pendidikan, Jakarta; Gaung P.

Yaumi, M., (2013), Prinsip-prinsip Desain Pembelajaran, Jakarta: Kencana Prenada Media Group. 